\title{
FEEDBACK LINEARIZING FIELD-ORIENTED CONTROL OF INDUCTION GENERATOR: THEORY AND EXPERIMENTS
}

\author{
S. Peresada, S. Kovbasa, S. Korol, N. Zhelinskyi \\ National Technical University of Ukraine "Igor Sikorsky Kyiv Polytechnic Institute", \\ Peremohy av., 37, 03056, Kyiv, Ukraine. \\ E-mail: sergei.peresada@gmail.com
}

\begin{abstract}
A novel field-oriented vector control for induction generators is presented. Design procedure is based on indirect field orientation concept and exploits output-feedback linearizing technique for voltage controller design. Proposed solution guarantees asymptotic rotor flux and DC-link voltage regulation together with linear nominal dynamics of the DC link voltage error. Decomposition into voltage and current-flux subsystems, based on the two-time scale separation, allows to use a simple controllers tuning procedure. Results of comparative experimental study with standard indirect field-oriented control, having linear PI voltage controller, are presented. It is shown that designed controller, in contrast to standard solutions, provides system performances stabilization when speed is varying. Proposed control algorithm is suitable for standalone and grid connected (via suitable inverter) energy generation systems with variable speed operation.
\end{abstract}

References 10, figures 8, table 1 .

Keywords: induction generator, field-oriented control, energy generation system.

Introduction. During last decades, there has been a growing trend to improve the efficiency of the electromechanical energy conversion process in electrical drives and energy generation systems. Variable speed generation is an attractive solution for many small and medium power energy plants: diesel, hydro and wind power stations [4], [6], aerospace and naval power systems [1]. The main advantage of the variable speed generation is higher achievable energy efficiency of the primary mover and electrical generator.

The most spread configuration of the energy generation systems consists of permanent magnet synchronous generator (PMSG) with AC-DC-AC power converter. Such structure established de facto the industrial standard for modern wind power stations. Nevertheless, the cost of PMSG is significantly higher than induction machine due to the use of rare-earth magnetic materials. The tendency to reduce the use of expensive rare-earth magnets has stimulated a renewed interest for development of advanced control for induction machine based energy generation (IG). The electromechanical systems on the base of vector controlled doubly-fed induction generators is well known solution for the systems with restricted speed variations of the primary mover [8]. The doubly-fed induction generator allows to produce constantfrequency electric power from a prime mover whose speed varies within a slip range, typically $20-30 \%$ of the generator synchronous speed. The converter needs only be rated for a fraction of the total output power, which depends on the allowable slip range [8].

Simple and cheap generation systems, based on capacitor self-excited squirrel cage induction machine [7], do not provide required accuracy of the voltage and frequency control. An alternative approach is known as induction generation under field-oriented control (FOC), reported in large number of publications since 1990th [3], [4], Fig. 1. The standard structure of the FOC generation system is simple a copy of the induction motor speed control system with speed PI controller replaced by the DC-bus PI voltage

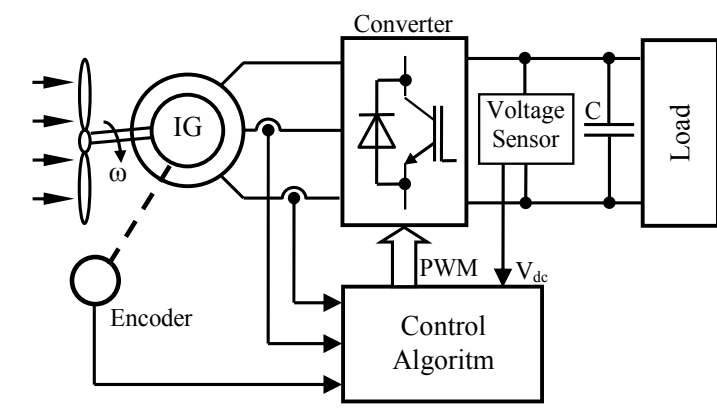

Fig. 1. Generation system structure controller. The similarity of the two system is based on fact that outputs of the both controllers (speed or voltage) form the reference signal for electric machine torque and consequently for torque producing component of the stator current vector. Flux subsystems for motor and generation operation are the same and use the direct or indirect field orientation.

The results in [2] - [5] report the basic approaches for DC-bus voltage and flux control of the IG. In [3] speed and flux variations are compensated in torque current computation, a novel nonlinear flux observer with

(C) Peresada S., Kovbasa S., Korol S., Zhelinskyi N., 2017 
saturation effect consideration is proposed. More recent publication [2] reports the system analysis based on some sort of linearized model and frequency domain approach. Active losses optimization is considered in [6]. Nevertheless no well-defined and theoretically justified solution of vector controlled IG is still available. The stability properties of the existing systems are not proven theoretically, as result controller tuning for performances specifications cannot be established and typically based on worst-case design consideration. This leads to reduced dynamic performance of the voltage control subsystem, when generator speed and flux are not constant.

The goal of this work is to develop a new IG output-feedback linearizing flux-voltage control algorithm, which in contrast to existing solutions, provides linear nominal DC link voltage error dynamics, and therefore allows specifying the dynamic performances of the voltage control loop.

Some preliminary results of this paper are given in [10], where system dynamic performance has been studied by simulation. In this paper, the results of experimental tests are presented in order to demonstrate the performances of proposed control during different operating conditions. Comparison with a standard solution, having PI voltage controller, is given as well.

This paper is organized as follows. The IG model and control problem formulation are given in Sections II. The flux-voltage controller is designed in Section III. In Section IV, the experimental and simulation results are reported followed by the Conclusions of the study.

II. PROBLEM STATEMENT. The standard two-phase model of the symmetrical induction generator, under the assumptions of linear magnetic circuits and balanced operating conditions, is represented in an arbitrary rotating reference frame (d-q) as [9]

$$
\begin{aligned}
& \dot{\mathrm{i}}_{\mathrm{d}}=-\gamma \mathrm{i}_{\mathrm{d}}+\omega_{0} \mathrm{i}_{\mathrm{q}}+\alpha \beta \psi_{\mathrm{d}}+\beta \omega \psi_{\mathrm{q}}+\mathrm{u}_{\mathrm{d}} / \sigma, \\
& \dot{\mathrm{i}}_{\mathrm{q}}=-\gamma \dot{\mathrm{i}}_{\mathrm{q}}-\omega_{0} \dot{\mathrm{i}}_{\mathrm{d}}+\alpha \beta \psi_{\mathrm{q}}-\beta \omega \psi_{\mathrm{d}}+\mathrm{u}_{\mathrm{q}} / \sigma, \\
& \dot{\psi}_{\mathrm{d}}=-\alpha \psi_{\mathrm{d}}+\left(\omega_{0}-\omega\right) \psi_{\mathrm{q}}+\alpha \mathrm{L}_{\mathrm{m}} \mathrm{i}_{\mathrm{d}}, \\
& \dot{\psi}_{\mathrm{q}}=-\alpha \psi_{\mathrm{q}}-\left(\omega_{0}-\omega\right) \psi_{\mathrm{d}}+\alpha \mathrm{L}_{\mathrm{m}} \mathrm{i}_{\mathrm{q}}, \\
& \dot{\varepsilon}_{0}=\omega_{0}, \varepsilon_{0}(0)=0, \\
& \mathrm{P}_{\mathrm{s}}=-(3 / 2)\left(\mathrm{u}_{\mathrm{d}} \mathrm{i}_{\mathrm{d}}+\mathrm{u}_{\mathrm{q}} \mathrm{i}_{\mathrm{q}}\right),
\end{aligned}
$$

where $\mathbf{u}=\left(\mathrm{u}_{\mathrm{d}}, \mathrm{u}_{\mathrm{q}}\right)^{\mathrm{T}}$ is the control vector of stator voltages, $\mathbf{i}=\left(\mathrm{i}_{\mathrm{d}}, \mathrm{i}_{\mathrm{q}}\right)^{\mathrm{T}}, \boldsymbol{\psi}=\left(\psi_{\mathrm{d}}, \psi_{\mathrm{q}}\right)^{\mathrm{T}}$ denote stator current and rotor flux vectors, $\omega$ is the rotor speed. Subscripts $d$ and $q$ stand for vector components in the $(d-q)$ reference frame, $\varepsilon_{0}$ is the angular position of the (d-q) reference frame with respect to a fixed stator reference frame $(a-b)$, where physical variables are defined; $P_{s}-$ active power produced by IG.

Positive constants related to the electrical and mechanical parameters of the IM are defined as follows: $\quad \alpha=\frac{\mathrm{R}_{2}}{\mathrm{~L}_{2}}, \sigma=\mathrm{L}_{1}\left(1-\frac{\mathrm{L}_{\mathrm{m}}^{2}}{\mathrm{~L}_{1} \mathrm{~L}_{2}}\right), \beta=\frac{\mathrm{L}_{\mathrm{m}}}{\sigma \mathrm{L}_{2}}, \gamma=\frac{\mathrm{R}_{1}}{\sigma}+\alpha \mathrm{L}_{\mathrm{m}} \beta$, where $\mathrm{R}_{1}, \mathrm{R}_{2}, \mathrm{~L}_{1}, \mathrm{~L}_{2}$ are stator/rotor resistances and inductances, respectively, $\mathrm{L}_{\mathrm{m}}$ is the magnetizing inductance. One pole pair is assumed without loss of generality.

Transformed variables in (1) are defined according to

$$
\mathbf{x}_{\mathrm{dq}}=\mathbf{e}^{-\mathrm{J} \varepsilon_{0}} \mathbf{x}_{\mathrm{ab}}, \quad \mathbf{x}_{\mathrm{ab}}=\mathbf{e}^{\mathrm{J} \varepsilon_{0}} \mathbf{x}_{\mathrm{dq}},
$$

where $\mathbf{e}^{-\mathbf{J} \varepsilon_{0}}=\left[\begin{array}{cc}\cos \varepsilon_{0} & \sin \varepsilon_{0} \\ -\sin \varepsilon_{0} & \cos \varepsilon_{0}\end{array}\right], \mathbf{J}=\left[\begin{array}{cc}0 & -1 \\ 1 & 0\end{array}\right], \mathbf{x}_{\mathrm{yz}}$ stands for two-dimensional voltage, flux and stator current vectors.

The electrical power $\mathrm{P}_{\mathrm{s}}$, produced by the IG, is transferred to DC-link by IGBT converter. Assuming ideal conversion without losses, the DC-link power $\mathrm{P}_{\mathrm{dc}}$ is equal to stator-generated power $\mathrm{P}_{\mathrm{s}}$. In this case DClink voltage $V_{\mathrm{dc}}$ dynamics is described by

$$
\begin{gathered}
\dot{\mathrm{V}}_{\mathrm{dc}}=\left(\mathrm{i}_{\mathrm{dc}}-\mathrm{i}_{\mathrm{L}}\right) / \mathrm{C}, \\
\mathrm{i}_{\mathrm{dc}}=\mathrm{P}_{\mathrm{dc}} / \mathrm{V}_{\mathrm{dc}}=\mathrm{P}_{\mathrm{s}} / \mathrm{V}_{\mathrm{dc}},
\end{gathered}
$$

where $\mathrm{C}-$ is DC-link capacitance, $\mathrm{i}_{\mathrm{dc}}-\mathrm{DC}$-link current from converter, $\mathrm{i}_{\mathrm{L}}-$ load current. 
Consider the IG and DC-link models (1) - (4) and assume that:

A1. The stator currents, rotor speed and load current are available for measurement. Rotor speed $\omega>0$ is slowly varying. All generator parameters and DC-link capacitance are known and constant.

A2. The DC-link voltage reference $V_{d c}^{*}>0$ is constant.

Under these assumptions, the control problem is to design a flux-voltage controller, which guarantees that following control objectives are achieved:

CO1. Asymptotic voltage regulation with all internal signals bounded, i.e.

$$
\lim _{\mathrm{t} \rightarrow \infty} \tilde{\mathrm{V}}_{\mathrm{dc}}=0 \text {, }
$$

where $\tilde{V}_{\mathrm{dc}}=\mathrm{V}_{\mathrm{dc}}-\mathrm{V}_{\mathrm{dc}}^{*}$ is voltage regulation error.

CO2. Asymptotic flux regulation:

$$
\lim _{t \rightarrow \infty} \tilde{\psi}=0,
$$

where $\tilde{\psi}=\psi-\psi^{*}-$ is a flux regulation error, $\psi-$ flux vector magnitude, $\psi^{*}>0$ - constant flux reference.

CO3. Asymptotic field orientation, i.e.

$$
\lim _{\mathrm{t} \rightarrow \infty} \psi_{\mathrm{q}}=0 .
$$

The following sections report the proposed solution to the formulated control problem.

\section{CONTROLLER DESIGN}

\section{A. Flux-current field-oriented controller}

Let consider the indirect field-oriented control algorithm for system (1) [9], which consist of

- flux controller

$$
\begin{aligned}
& \dot{\varepsilon}_{0}=\omega_{0}=\omega+\alpha \mathrm{L}_{\mathrm{m}} \mathrm{i}_{\mathrm{q}} / \psi^{*}, \\
& \mathrm{i}_{\mathrm{d}}^{*}=\left(\alpha \psi^{*}+\dot{\psi}\right) / \alpha \mathrm{L}_{\mathrm{m}},
\end{aligned}
$$

- current controllers

$$
\begin{aligned}
& \mathrm{u}_{\mathrm{d}}=\sigma\left(\gamma \mathrm{i}_{\mathrm{d}}^{*}-\omega_{0} \mathrm{i}_{\mathrm{q}}-\alpha \beta \psi^{*}-\mathrm{k}_{\mathrm{i}} \tilde{\mathrm{i}}_{\mathrm{d}}+\mathrm{x}_{\mathrm{d}}\right), \\
& \dot{\mathrm{x}}_{\mathrm{d}}=-\mathrm{k}_{\mathrm{ii}} \tilde{\mathrm{i}}_{\mathrm{d}}, \\
& \mathrm{u}_{\mathrm{q}}=\sigma\left(\gamma \mathrm{i}_{\mathrm{q}}^{*}+\omega_{0} \dot{\mathrm{i}}_{\mathrm{d}}+\beta \omega \psi^{*}-\mathrm{k}_{\mathrm{i}} \tilde{\mathrm{i}}_{\mathrm{q}}+\mathrm{x}_{\mathrm{q}}\right), \\
& \dot{\mathrm{x}}_{\mathrm{q}}=-\mathrm{k}_{\mathrm{ii}} \tilde{\mathrm{i}}_{\mathrm{q}},
\end{aligned}
$$

where $\tilde{i}_{d}=i_{d}-i_{d}^{*}$ and $\tilde{i}_{q}=i_{q}-i_{q}^{*}$ are current tracking errors, $i_{d}^{*}, i_{q}^{*}-$ are references for $i_{d}$ and $i_{q}$ currents respectively, $x_{d}, x_{q}-$ integral terms of current controllers, $\left(k_{i}, k_{i i}\right)$ are the current controller's proportional and integral gains.

Assume that $i_{q}^{*}$ and $i_{d}^{*}$ are slowly varying signal with respect of stator current dynamics, so that $i_{\mathrm{d}}^{*}=\dot{i}_{\mathrm{q}}^{*}=0$. Under these conditions, the current-flux error dynamics can be written as

$$
\begin{aligned}
& \dot{\tilde{\mathrm{i}}}_{\mathrm{d}}=-\left(\mathrm{k}_{\mathrm{i}}+\gamma\right) \tilde{\mathrm{i}}_{\mathrm{d}}-\mathrm{x}_{\mathrm{d}}+\alpha \beta \tilde{\Psi}_{\mathrm{d}}+\beta \omega \tilde{\Psi}_{\mathrm{q}}, \\
& \dot{\mathrm{x}}_{\mathrm{d}}=\mathrm{k}_{\mathrm{ii}} \tilde{\mathrm{i}}_{\mathrm{d}}, \\
& \dot{\tilde{\mathrm{i}}}_{\mathrm{q}}=-\left(\mathrm{k}_{\mathrm{i}}+\gamma\right) \tilde{\mathrm{i}}_{\mathrm{q}}-\mathrm{x}_{\mathrm{q}}+\alpha \beta \tilde{\Psi}_{\mathrm{q}}-\beta \omega \tilde{\Psi}_{\mathrm{d}}, \\
& \dot{\mathrm{x}}_{\mathrm{q}}=\mathrm{k}_{\mathrm{ii}} \tilde{\mathrm{i}}_{\mathrm{q}}, \\
& \dot{\tilde{\Psi}}_{\mathrm{d}}=-\alpha \tilde{\Psi}_{\mathrm{d}}+\omega_{2} \tilde{\Psi}_{\mathrm{q}}+\alpha \mathrm{L}_{\mathrm{m}} \tilde{\mathrm{i}}_{\mathrm{d}}, \\
& \dot{\tilde{\Psi}}_{\mathrm{q}}=-\alpha \tilde{\Psi}_{\mathrm{q}}-\omega_{2} \tilde{\Psi}_{\mathrm{d}},
\end{aligned}
$$


where $\tilde{\psi}_{\mathrm{d}}=\psi_{\mathrm{d}}-\psi^{*}, \tilde{\psi}_{\mathrm{q}}=\psi_{\mathrm{q}}-$ are the flux tracking errors, $\omega_{2}=\left(\omega_{0}-\omega\right)$.

For high enough current controllers gains $\mathrm{k}_{\mathrm{i}}, \mathrm{k}_{\mathrm{ii}}$ we obtain current-fed condition such that

$$
\left(\tilde{i}_{d}, \tilde{i}_{q}\right)=0 \text {, }
$$

and as it follows from (12) we have

$$
\lim _{\mathrm{t} \rightarrow \infty}\left(\tilde{\psi}_{\mathrm{d}}, \tilde{\Psi}_{\mathrm{q}}\right)=0 .
$$

Stability conditions for the system (12) are derived using Lyapunov's method in [9]. From condition (14) we conclude that both rotor flux modulus regulation and asymptotic field orientation (CO2 and CO3) are achieved.

\section{B. Feedback linearizing voltage controller}

From conditions (13), (14) and $i_{d}^{*}=i_{q}^{*}=0$ it follows that $\left(x_{d}, x_{q}\right)=0$, therefore from (9), (10) we obtain

$$
\begin{aligned}
& \mathrm{u}_{\mathrm{d}}=\mathrm{R}_{1} \mathrm{i}_{\mathrm{d}}^{*}-\sigma \omega_{0} \mathrm{i}_{\mathrm{q}}^{*}, \\
& \mathrm{u}_{\mathrm{q}}=\mathrm{R}_{1} \mathrm{i}_{\mathrm{q}}^{*}+\alpha \mathrm{L}_{\mathrm{m}}^{2} \mathrm{i}_{\mathrm{q}}^{*} / \mathrm{L}_{2}+\sigma \omega_{0} \mathrm{i}_{\mathrm{d}}^{*}+\mathrm{L}_{\mathrm{m}} \omega \psi^{*} / \mathrm{L}_{2} .
\end{aligned}
$$

Using (15) the IG output power is computed as

$$
\mathrm{P}_{\mathrm{s}}=-\frac{3}{2}\left(\mathrm{R}_{1}\left(\mathrm{i}_{\mathrm{d}}^{* 2}+\mathrm{i}_{\mathrm{q}}^{* 2}\right)+\mathrm{R}_{2} \frac{\mathrm{L}_{\mathrm{m}}^{2}}{\mathrm{~L}_{2}^{2}} \mathrm{i}_{\mathrm{q}}^{* 2}+\frac{\mathrm{L}_{\mathrm{m}}}{\mathrm{L}_{2}} \omega \psi^{*} \mathrm{i}_{\mathrm{q}}^{*}\right)
$$

According to (16) and under conditions (13), (14), $\dot{i}_{d}^{*}=\dot{i}_{q}^{*}=0$ the stator output power consist of three components: active loses of the stator circuit (proportional to $\mathrm{R}_{1}$ ), active rotor loses (proportional to $\mathrm{R}_{2}$ ) and input mechanical power

$$
\mathrm{P}_{\mathrm{m}}=\frac{3}{2} \frac{\mathrm{L}_{\mathrm{m}}}{\mathrm{L}_{2}} \psi^{*} \mathrm{i}_{\mathrm{q}}^{*} \omega=\frac{3}{2} \frac{\mathrm{L}_{\mathrm{m}}}{\mathrm{L}_{2}} \psi \mathrm{i}_{\mathrm{q}} \omega=\mathrm{T} \omega,
$$

where $\mathrm{T}$ - is electromagnetic torque.

Using equations (3), (4), (15) we can derive

$$
\dot{\mathrm{V}}_{\mathrm{dc}}=-\frac{1}{\mathrm{C}} \frac{3}{2 \mathrm{~V}_{\mathrm{dc}}}\left(\mathrm{R}_{1}\left[\frac{\psi^{* 2}}{\mathrm{~L}_{\mathrm{m}}^{2}}+\mathrm{i}_{\mathrm{q}}^{* 2}\right]+\mathrm{R}_{2} \frac{\mathrm{L}_{\mathrm{m}}^{2}}{\mathrm{~L}_{2}^{2}} \mathrm{i}_{\mathrm{q}}^{* 2}+\frac{\mathrm{L}_{\mathrm{m}}}{\mathrm{L}_{2}} \omega \psi^{*} \dot{\mathrm{i}}_{\mathrm{q}}^{*}\right)-\mathrm{i}_{\mathrm{L}} / \mathrm{C},
$$

and voltage error regulation dynamics becomes $\left(\mathrm{V}_{\mathrm{dc}}^{*}=\right.$ const $)$

$$
\dot{\tilde{V}}_{\mathrm{dc}}=-\frac{1}{\mathrm{C}} \frac{3}{2 \mathrm{~V}_{\mathrm{dc}}}\left(\mathrm{R}_{1}\left[\frac{\psi^{* 2}}{\mathrm{~L}_{\mathrm{m}}^{2}}+\mathrm{i}_{\mathrm{q}}^{* 2}\right]+\mathrm{R}_{2} \frac{\mathrm{L}_{\mathrm{m}}^{2}}{\mathrm{~L}_{2}^{2}} \mathrm{i}_{\mathrm{q}}^{* 2}+\frac{\mathrm{L}_{\mathrm{m}}}{\mathrm{L}_{2}} \omega \psi^{*} \mathrm{i}_{\mathrm{q}}^{*}\right)-\mathrm{i}_{\mathrm{L}} / \mathrm{C} .
$$

In (19) a torque component of the stator current reference $i_{q}^{*}$ is a control input, while $i_{L}$ is perturbation (measurable signal).

Let us define a desired voltage dynamics as given by the second order linear asymptotically stable system in the following form

$$
\begin{aligned}
& \dot{\tilde{\mathrm{V}}}_{\mathrm{dc}}=-\mathrm{k}_{\mathrm{v}} \tilde{\mathrm{V}}_{\mathrm{dc}}+\mathrm{x}_{\mathrm{v}}, \\
& \dot{\mathrm{X}}_{\mathrm{v}}=-\mathrm{k}_{\mathrm{vi}} \tilde{\mathrm{V}}_{\mathrm{dc}},
\end{aligned}
$$

where $\left(\mathrm{k}_{\mathrm{v}}, \mathrm{k}_{\mathrm{vi}}\right)>0$ are the proportional and integral gains of voltage controller.

Feedback linearizing voltage controller from (19) and (20) is given by the solution of nonlinear algebraic equation 


$$
\begin{aligned}
& -\frac{1}{\mathrm{C}} \frac{3}{2 \mathrm{~V}_{\mathrm{dc}}}\left(\mathrm{R}_{1}\left[\frac{\psi^{* 2}}{\mathrm{~L}_{\mathrm{m}}^{2}}+\mathrm{i}_{\mathrm{q}}^{*_{2}}\right]+\mathrm{R}_{2} \frac{\mathrm{L}_{\mathrm{m}}^{2}}{\mathrm{~L}_{2}^{2}} \mathrm{i}_{\mathrm{q}}^{*}+\frac{\mathrm{L}_{\mathrm{m}}}{\mathrm{L}_{2}} \omega \psi^{*} \mathrm{i}_{\mathrm{q}}^{*}\right)-\mathrm{i}_{\mathrm{L}} / \mathrm{C}=-\mathrm{k}_{\mathrm{v}} \tilde{\mathrm{V}}_{\mathrm{dc}}+\mathrm{x}_{\mathrm{v}} \\
& \dot{\mathrm{x}}_{\mathrm{v}}=-\mathrm{k}_{\mathrm{vi}} \tilde{\mathrm{V}}_{\mathrm{dc}}
\end{aligned}
$$

as follows

$$
\begin{aligned}
& \mathrm{i}_{\mathrm{q}}^{*}=-\frac{\mathrm{L}_{\mathrm{m}}}{\mathrm{L}_{2}} \omega \psi^{*}+\sqrt{\left(\frac{\mathrm{L}_{\mathrm{m}}}{\mathrm{L}_{2}} \omega \psi^{*}\right)^{2}-4\left(\alpha \frac{\mathrm{L}_{\mathrm{m}}^{2}}{\mathrm{~L}_{2}}+\mathrm{R}_{1}\right) \rho} / 2\left(\alpha \frac{\mathrm{L}_{\mathrm{m}}^{2}}{\mathrm{~L}_{2}}+\mathrm{R}_{1}\right), \\
& \rho=\mathrm{R}_{1} \psi^{* 2} \mathrm{~L}_{\mathrm{m}}^{-2}+(2 / 3) \mathrm{V}_{\mathrm{dc}}\left(\mathrm{i}_{\mathrm{L}}+\mathrm{C}\left(-\mathrm{k}_{\mathrm{v}} \tilde{\mathrm{V}}_{\mathrm{dc}}+\mathrm{x}_{\mathrm{v}}\right)\right), \\
& \dot{\mathrm{x}}_{\mathrm{v}}=-\mathrm{k}_{\mathrm{vi}} \tilde{\mathrm{V}}_{\mathrm{dc}} .
\end{aligned}
$$

Solution for the voltage controller (22) establishes a physical limitation $\left(\mathrm{L}_{\mathrm{m}} \omega \psi^{*} / \mathrm{L}_{2}\right)^{2}-4\left(\alpha \mathrm{L}_{\mathrm{m}}^{2} / \mathrm{L}_{2}+\mathrm{R}_{1}\right) \rho>0$ for energy conversion using fully controlled AC-DC converter, which is standard condition for such systems. Since variable $\rho$ is error dependent $\left(\tilde{V}_{d c}, x_{v}\right)$ this solution is local. If $\psi^{*}=$ const,$V_{d c}^{*}=$ const,$\omega$ and $i_{L}$ are slowly varying, $\left(\tilde{V}_{\mathrm{dc}}, x_{v}\right)$ - small enough, voltage controller gains $\left(k_{v}, k_{v i}\right)>0$ are small with respect of current controller gains $\left(k_{i}, k_{i i}\right)$, then $i_{q}^{*}$ is slowly varying and therefore assumption $i_{q}^{*}=0$ is valid. From this analysis it follows that according to solutions of (20) $\lim _{\mathrm{t} \rightarrow \infty} \tilde{\mathrm{V}}_{\mathrm{dc}}=0$, and therefore asymptotic voltage regulation (CO1) is locally achieved. A controller block diagram is shown in Fig. 2.

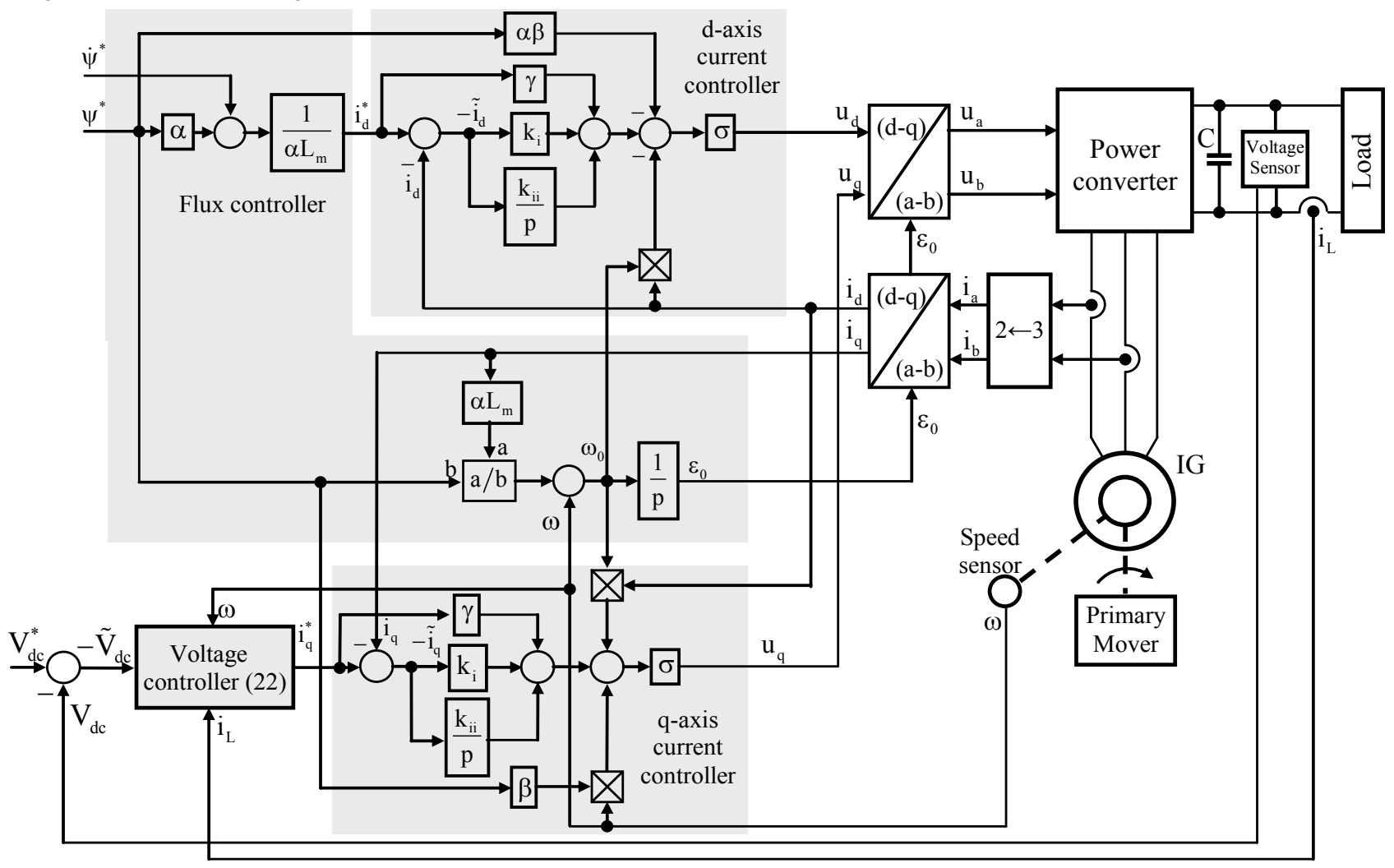

Fig. 2. Block diagram of the voltage control system with feedback linearizing controller

Based on analysis above we conclude that for slowly varying signals in right hand side of (22) the dynamics of the voltage control loop can be designed much slower than current loops dynamics (11) providing the two-time scale separation, needed to justify a common assumption for current fed IG control.

Under these conditions the system error dynamics is given by (20), (11), (12) and allows separated considerations of the two subsystems: voltage control loop (20) and flux-current error dynamics (11), (12). 
System tuning is provided by selection of proportional and integral gains for voltage and current controllers as

$$
\mathrm{k}_{\mathrm{vi}}=\mathrm{k}_{\mathrm{v}}{ }^{2} / 2, \quad \mathrm{k}_{\mathrm{ii}}=\left(\mathrm{k}_{\mathrm{i}}+\gamma\right)^{2} / 2 .
$$

Such tuning provides damping factor $\xi=\sqrt{2} / 2$ for each control loop. Natural frequency of undamped oscillations is given by $\omega_{\mathrm{ov}}^{2}=\mathrm{k}_{\mathrm{vi}}$ for voltage controller and $\omega_{0 \mathrm{i}}^{2}=\mathrm{k}_{\mathrm{ii}}$ for current controllers. The two-time scale separation between voltage and current loops is satisfied for condition $\omega_{0 \mathrm{i}}>(3-4) \omega_{\mathrm{ov}}$.

From this stability analysis it follows that $\lim _{\mathrm{t} \rightarrow \infty}\left(\tilde{\psi}_{\mathrm{d}}, \tilde{\psi}_{\mathrm{q}}, \tilde{\mathrm{i}}_{\mathrm{d}}, \tilde{\mathrm{i}}_{\mathrm{q}}\right)=0, \lim _{\mathrm{t} \rightarrow \infty} \tilde{\mathrm{V}}_{\mathrm{dc}}=0$, and therefore control objectives CO1-CO3 are locally achieved if $\left(\mathrm{L}_{\mathrm{m}} \omega \psi^{*} / \mathrm{L}_{2}\right)^{2}-4\left(\alpha \mathrm{L}_{\mathrm{m}}^{2} / \mathrm{L}_{2}+\mathrm{R}_{1}\right) \rho>0$.

Remark. For $\mathrm{i}_{\mathrm{L}}=$ const a compensation term $\mathrm{i}_{\mathrm{L}}$ may be removed from feedback linearizing controller (22) leaving $i_{L}$ compensation for the integral action of the voltage controller.

IV. EXPERIMENTAL STUDIES. The experiments are carried out using the Rapid Prototyping Station, which includes (Fig. 3): (1) induction generator (see rated data in Table 1) coupled with DC- motor used as primary mover; (2) three-phase PWM controlled converter, operated at $5 \mathrm{kHz}$ switching frequency; (3) commutated load resistance $\mathrm{R}_{\mathrm{L}}$; (4) DSP TMS320F28335 controller which performs data acquisition, implements control algorithms with programmable tracing of selected variables; (5) personal computer for processing, programming, interactive oscilloscope, data acquisition, etc. The motor speed is measured by a $2500 \mathrm{pulse} /$ revolution optical encoder. The sampling time is set at $200 \mu \mathrm{s}$. DC-link capacitance is equal to

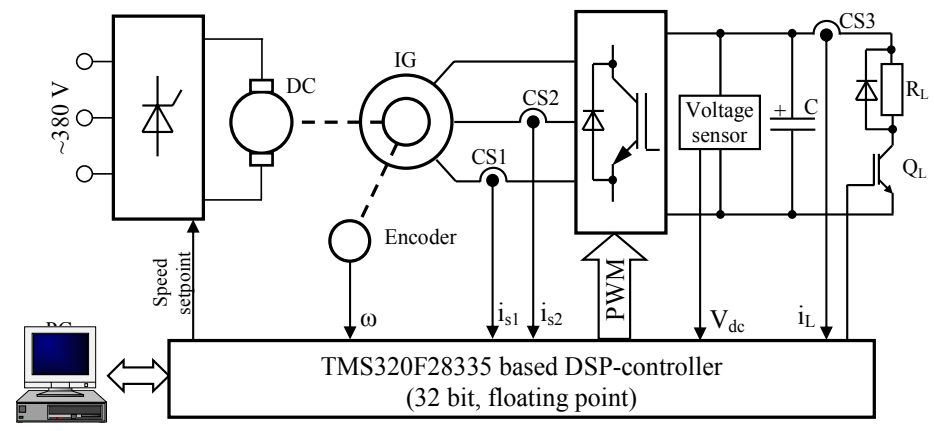

Fig. 3. Experimental set-up of induction generator electromechanical system

During all experiments, rotor speed is controlled by industrial closed loop DC-drive. In order to compare proposed solution with the standard PI controller, described in [10], we eliminate compensation of the load current $i_{L}$ in (22) at the first stage of experiments.

Tuning parameters of the controller are set to: current controller (9), (10) $\mathrm{k}_{\mathrm{i}}=600, \quad \mathrm{k}_{\mathrm{ii}}=\left(\mathrm{k}_{\mathrm{i}}+\gamma\right)^{2} / 2 ; \quad$ voltage controller (22) $\mathrm{k}_{\mathrm{v}}=125, \mathrm{k}_{\mathrm{vi}}=\mathrm{k}_{\mathrm{v}}^{2} / 2$; standard PI controller [10] $\mathrm{k}_{\mathrm{v}}=0.15, \mathrm{k}_{\mathrm{vi}}=15$. Standard and developed controllers are tuned to provide the same performances when system operates at speed $140 \mathrm{rad} / \mathrm{s}$.

Table 1. IG parameters

\begin{tabular}{|l|l|l|l|}
\hline Rated mechanical power & $5.5 \mathrm{~kW}$ & Stator resistance & $1.04 \mathrm{Ohm}$ \\
\hline Rated phase voltage, rms & $220 \mathrm{~V}$ & Rotor resistance & $0.7 \mathrm{Ohm}$ \\
\hline Rated phase current, rms & $11 \mathrm{~A}$ & Stator inductance & $0.124 \mathrm{H}$ \\
\hline Rated frequency & $50 \mathrm{~Hz}$ & Rotor inductance & $0.124 \mathrm{H}$ \\
\hline Number of pole pairs & 2 & Magnetizing inductance & $0.118 \mathrm{H}$ \\
\hline
\end{tabular}

All tests are performed using the following operating sequences (Fig. 4):

- at initial time the DC-link voltage is charged to $290 \mathrm{~V}$, rotor speed is stabilized by the primary mover at $\omega=140 \mathrm{rad} / \mathrm{s}$;

- initial time interval $0 \ldots 0.3 \mathrm{~s}$ is used to excite the generator by applying flux reference trajectory, reported in Fig. 4, with $\psi^{*}(0)=0.02 \mathrm{~Wb}$ and reached the value of $0.5 \mathrm{~Wb}$ (low flux level is used in order to prevent converter voltage saturation during system start-up with low level of $\mathrm{V}_{\mathrm{dc}}$ ); 
- starting at $\mathrm{t}=0.5 \mathrm{~s}$, the voltage reference increases to $540 \mathrm{~V}$ with first time derivative equals to $500 \mathrm{~V} / \mathrm{s}$

- starting at $\mathrm{t}=1.5 \mathrm{~s}$, the flux reference increases to $\psi^{*}=0.96 \mathrm{~Wb}$ in order to achieve IG operation with rated flux;

- at time $\mathrm{t}=2 \mathrm{~s}$ the load current equal to $6.7 \mathrm{~A}$ (correspond to $3.6 \mathrm{~kW}$ of power, $80 \%$ of rated value) is applied and at $\mathrm{t}=5.5 \mathrm{~s}$ is removed;

- under load condition a speed variations are applied: starting from $\mathrm{t}=2.5 \mathrm{~s}$ speed increased to 150 $\mathrm{rad} / \mathrm{s}$ and from $\mathrm{t}=3.5 \mathrm{~s}$ is decreased to $130 \mathrm{rad} / \mathrm{s}$.
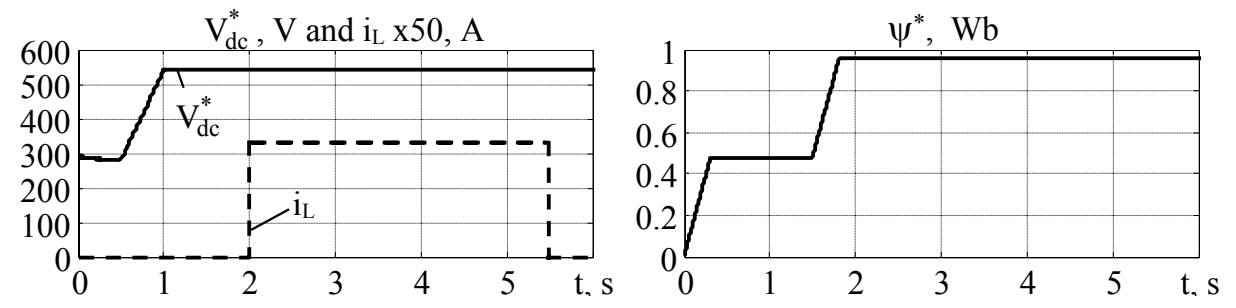

Experimental results for proposed voltage control algorithm (8)-(10), (22) are shown in Fig. 5. Flux and voltage tracking errors as well as currents $i_{d}$ and $i_{q}$ during simulation are depicted in Fig. 6. As it

Fig. 4. Flux, voltage reference trajectories and load current profile

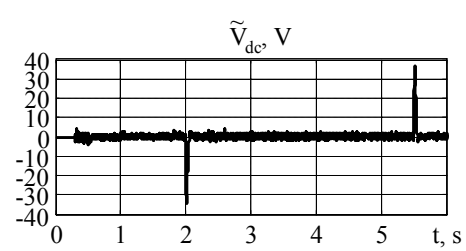

$i_{d}, A$
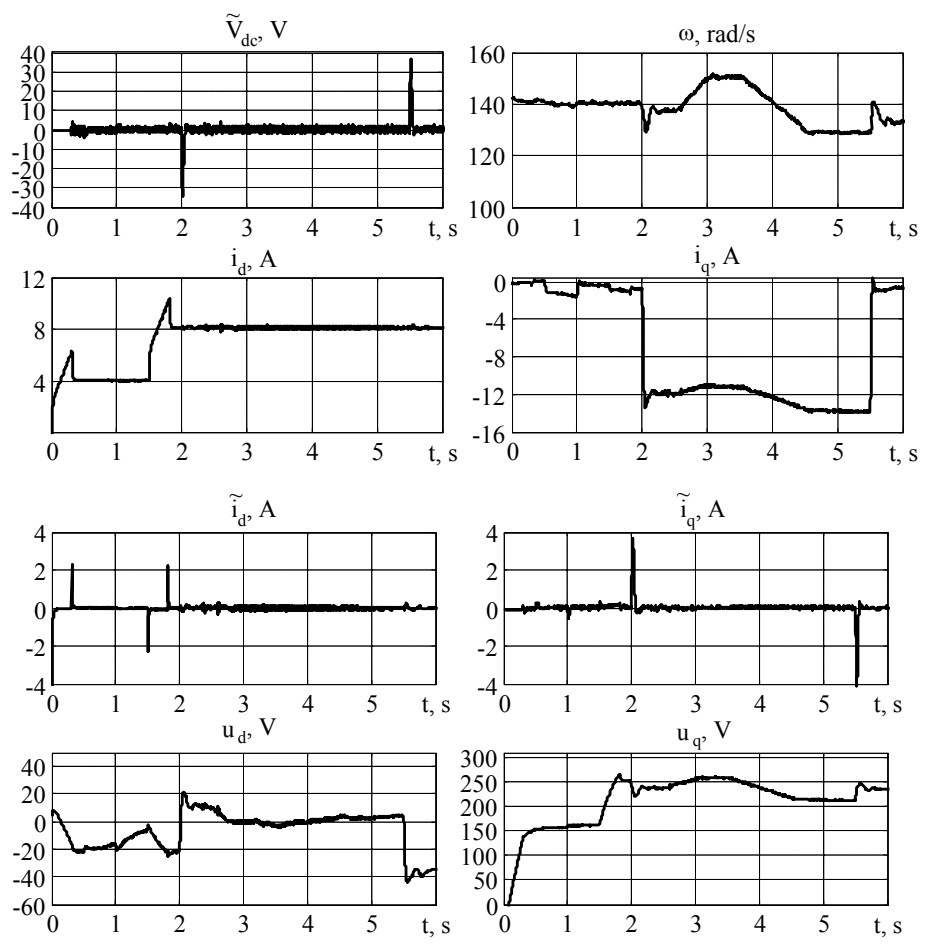

Fig. 5. Transients during flux-voltage regulation: experimental results
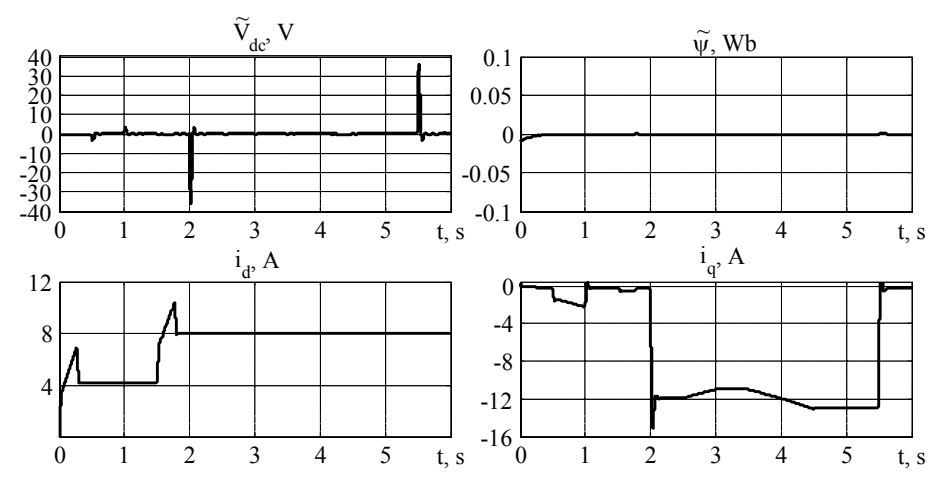
in Fig. 5 and Fig. 6 the proposed control algorithm provides speed variation condition. Experimental transients are close to results of simulation.

Transients with $i_{L}$ compensation in control algorithm (22) are shown in Fig. 7. Due to presence of $i_{L}$ compensation a dynamical voltage error at $\mathrm{t}=2 \mathrm{~s}$ and $\mathrm{t}=5.5 \mathrm{~s}$ is reduced to negligible level.

In order to compare dynamic behavior of the standard PI and developed feedback linearizing voltage controllers for different constant speeds $\omega=140 \mathrm{rad} / \mathrm{s}$ and $\omega=75 \mathrm{rad} / \mathrm{s}$ we perform the additional experimental test. During this tests the load current ( $33 \%$ of rated value) is applied at $t=$ $=0.2 \mathrm{~s}$ and removed at $\mathrm{t}=0.6 \mathrm{~s}$. Transients for both controllers are depicted in Fig. 8.

From voltage error evolutions reported in Fig. 8 it follows that both controllers provides the same dynamic behavior when system operates at speed 140 $\mathrm{rad} / \mathrm{s}$. Performances of the proposed controller are independent from generator speed. At the same time dynamics of standard controller deteriorates when $\omega=75 \mathrm{rad} / \mathrm{s}$ with almost twice increasing of the dynamical voltage error.

Note that systems under experimental comparison demonstrates similar to [10] dynamic behavior, which has been obtained by simulations with $2.2 \mathrm{~kW}$ generator.

Fig. 6. Transients during flux-voltage regulation: 

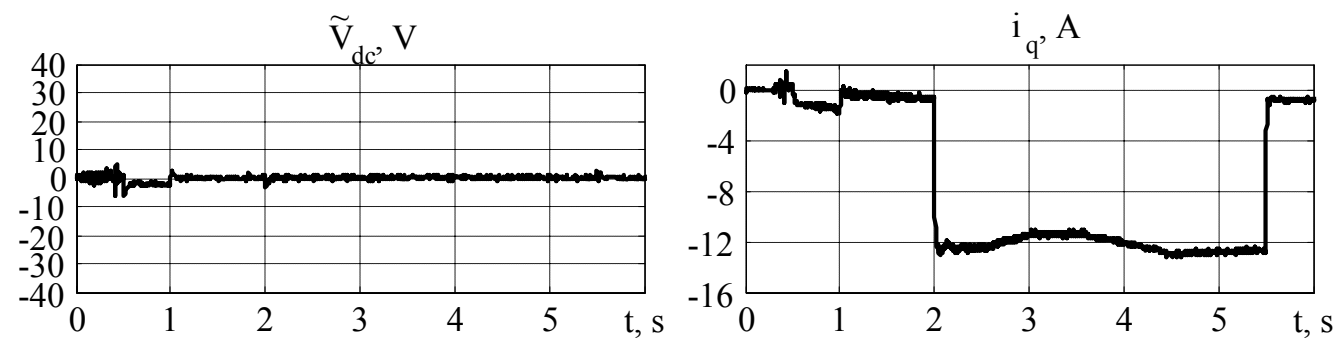

Fig. 7. Transients with $i_{L}$ compensation
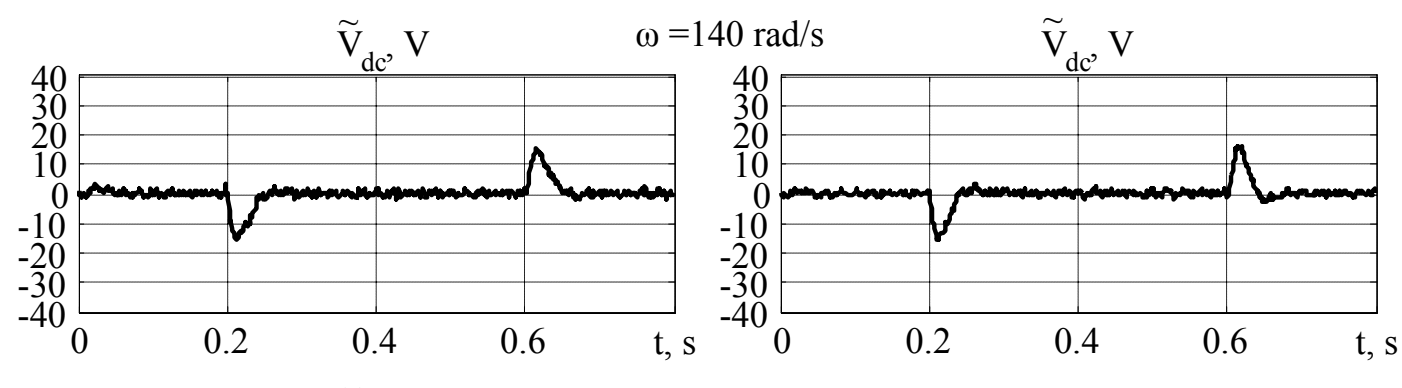

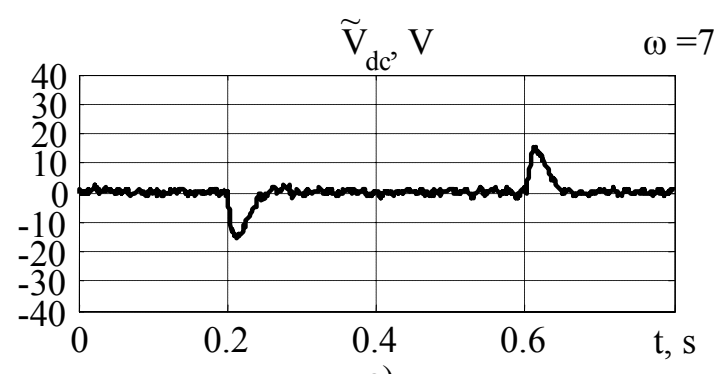

a)

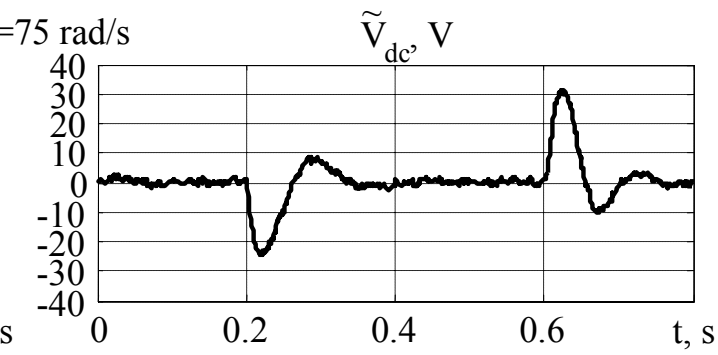

b)

Fig. 8. DC-link voltage regulation at speed $140 \mathrm{rad} / \mathrm{s}$ and $75 \mathrm{rad} / \mathrm{s}$. Experimental results:

a) proposed controller (8)-(10), (22); b) standard PI voltage controller

V. CONCLUSIONS. In this paper, a novel indirect field-oriented controller for induction generator based on output-feedback linearizing technique has been designed and experimentally verified. The nonlinear control algorithm guarantees local asymptotic voltage-flux regulation under variable speed conditions. The proposed design approach provides simple and substantiated controller tuning procedure. An intensive experimental study of the proposed solution and comparison with standard PI voltage controller has proved that, in contrast to existing solutions, feedback-linearizing controller provides system performances stabilization when speed and flux are varying. Experimental transients are close to simulation results. Designed controller is suitable for standalone and grid connected (via suitable inverter) energy generation systems with variable speed operation.

1. Feehally T., Apsley J.M. The Doubly Fed Induction Machine as an Aero Generator // IEEE Transactions on Industry Applications. - 2015. - Vol. 51. - No 4. - Pp. 3462-3471.

2. Hazra S., Sensarma P. DC bus voltage build up and control in stand-alone wind energy conversion system using direct vector control of SCIM // IEEE Proceedings - Electric Power Applications. - 2008. - Vol. 2. - Pp. 2143-2148.

3. Levi E., Liao Y. Rotor Flux Oriented Induction Machine as a DC Power Generator / Proceedings of 8th European Conf. on Power Electronics and Applications EPE. - Lausanne, Switzerland, CD-ROM, Paper No. 001.pdf, 1999.

4. Lyra R.O.C., Silva S.R., Cortizo P.C. Direct and indirect flux control of an isolated induction generator // Proceedings of 1995 International Conference on Power Electronics and Drive Systems, PEDS 95. - 1995. - Vol. 1. Pp. 140-145. 
5. Mazurenko L., Romanenko V., Dzura O. Implementation and experimental study of the induction generator with vector control // Elektromechanical and energy systems. Quarterly research and production journal. - 2015. - Vol. 4/2015(32). - Pp. 34-30. (Rus)

6. Mesemanolis A., Mademlis C., Kioskeridis I. High-Efficiency Control for a Wind Energy Conversion System With Induction Generator // IEEE Transactions on Energy Conversion. - 2012. - Vol. 27. - No 4. - Pp. 958-967.

7. Murthy S., Malik O., Tandon A. Analysis of self-excited induction generators // IEE Proceedings C - Generation, Transmission and Distribution. - 1982. - Vol. 129. - No 6. - Pp. 260-265.

8. Pena R., Clare J.C., Asher G.M. A doubly fed induction generator using back-to-back PWM converters supplying an isolated load from a variable speed wind turbine // IEE Proceedings - Electric Power Applications. 1996. - Vol. 143. - No 5. - Pp. 380-387.

9. Peresada S., Tonielli A. High-performance robust speed-flux tracking controller for induction motor // International Journal of Adaptive Control and Signal Processing. - 2000 . - Vol. 14. - Pp. 177-200.

10. Peresada S., Kovbasa S., Korol S., Pechenik N., Zhelinskyi N. Indirect Field Oriented Output Feedback Linearized Control of Induction Generator / Proceedings of 2016 IEEE 2nd International Conference on Intelligent Energy and Power Systems (IEPS). - 2016. - Pp. 187-191.

\section{УДК 681.5: 62-83 \\ ПОЛЕОРІСНТОВАНЕ ЛІНЕАРИЗУЮЧЕ КЕРУВАННЯ АСИНХРОННИМ ГЕНЕРАТОРОМ: ТЕОРІЯ ТА ЕКСПЕРИМЕНТИ}

С. Пересада, докт.техн.наук, С. Ковбаса, канд.техн.наук, С. Король, канд.техн.наук, М. Желінський Національний технічний університет України "Київський політехнічний інститут ім. Ігоря Сікорського", пр. Перемоги, 37, 03056, Київ, Україна. $\quad$ E-mail: sergei.peresada@gmail.com

Представлено нову систему векторного керування асинхронними генераторами. Прочедура проектування базується на концепиї̈ непрямої орієнтації за вектором потокозчеплення ротора $і$ використовує метод лінеаризації зворотнім зв'язком для проектування регулятора напруги. Запропоноване рішення гарантує асимптотичне регулювання потокозчеплення ротора і напруги в ланиі постійного струму, забезпечуючи лінійну динаміку похибки регулювання напруги. Завдяки розділенню контурів регулювання в часі досягається декомпозиція на підсистему напруги і підсистему струму-потокозчеплення, щзо дозволяє використовувати просту процедуру налаштування регуляторів. У роботі представлені результати порівняльного експериментального дослідження запропонованого алгоритму і стандартного, який базується на алгоритмі з непрямою орієнтацією за потокозчепленням ротора і використовує лінійний ПI регулятор напруги. Показано, щзо розроблений контролер, на відміну від стандартних рішень, забезпечує стабілізачію показників якості системи при зміні кутової швидкості ротора генератора. Запропонований алгоритм керування може застосовуватися в системах генерування зі змінною робочою швидкістю, які працюють в автономному режимі чи підключені до мережі через відповідний інвертор. Бібл. 10, рис. 8, табл. 1.

Ключові слова: асинхронний генератор, полеорієнтоване керування, система генерування енергії.

УДК 681.5: 62-83

ПОЛЕОРИЕНТИРОВАННОЕ ЛИНЕАРИЗИРУЮЩЕЕ УПРАВЛЕНИЕ АСИНХРОННЫМ ГЕНЕРАТОРОМ: ТЕОРИЯ И ЭКСПЕРИМЕНТЫ

С. Пересада, докт.техн.наук, С. Ковбаса, канд.техн.наук, С. Король, канд.техн.наук, Н. Желинский Национальный технический университет Украины "Киевский политехнический институт им. Игоря Сикорского", пр. Победы, 37, 03056, Киев, Украина. $\quad$ E-mail: sergei.peresada@gmail.com Представлена новая система векторного управления асинхронными генераторами. Процедура проектирования базируется на концепции косвенной ориентации по вектору потокосиепления ротора и использует метод линеаризации обратной связью для проектирования регулятора напряжения. Предложенное решение гарантирует асимптотическое регулирование потокосиепления ротора и напряжения в звене постоянного тока, обеспечивая линейную динамику ошибки регулирования напряжения. Благодаря разделению контуров регулирования во времени достигается декомпозиция на подсистему напряжения и подсистему тока-потокосиепления, что позволяет использовать простую процедуру настройки регуляторов. В работе представлень результать сравнительного экспериментального исследования предложенного алгоритма и стандартного, который основан на алгоритме с косвенной ориентацией по потокосиеплению ротора и использует линейный ПИ регулятор напряжения. Показано, что разработанный контроллер, в отличие от стандартных решений, обеспечивает стабилизацию показателей качества системы при изменении угловой скорости ротора генератора. Предложенный алгоритм управления может применяться в системах генерирования с переменной рабочей скоростью, которые работают в автономном режиме или подключены к сети через соответствующий инвертор. Библ. 10 , рис. 8 , табл. 1 .

Ключевые слова: асинхронный генератор, полеориентированное управление, система генерирования энергии. 